\title{
Pedagogical Technologies for Competent Training of Teachers in Ukrainian Professional Education
}

\author{
${ }^{1}$ Yevhen Kulyk, ${ }^{2}$ Liubov Kravchenko, ${ }^{3}$ Mykola Blyzniuk, ${ }^{4}$ Liudmyla Chystiakova, ${ }^{5}$ Nataliia Orlova, \\ ${ }^{6}$ Andrii Bukhun \\ 1,2,3,5 Poltava V.G. Korolenko National Pedagogical University. Poltava, Ukraine \\ ${ }^{4}$ Volodymyr Vynnychenko Central Ukrainian State Pedagogical University, Kropivnitsky, Ukraine \\ ${ }^{6}$ National Academy of the National Guard of Ukraine, Kharkiv, Ukraine
}

Received: March 15, 2021. Revised: November 7, 2021. Accepted: December 6, 2021. Published: January 4, 2022.

\begin{abstract}
In recent decades, technological advances have revolutionized all areas of society, including the teaching resources and methodologies used in education. The relevance of pedagogical technologies in vocational education cannot be overemphasized, since technologies are constantly changing in today's environment, thus creating new challenges for modern education in globalization. The research aims are to establish patterns for promoting the implementation of pedagogical technologies in educational institutions for providing quality competent training of specialists in professional education. Research methods: comparative analysis; survey; systematization, generalization. As a result of the survey was established that pedagogical technologies positively influence the provision of competent training of specialists in Ukrainian professional education $(89.7 \%$ ), a smaller number of students $(\mathbf{7 . 5 \%})$ were not sure about the quality of competent training of specialists in Ukrainian professional education with modern pedagogical technologies. It was determined that the students of educational institutions are most familiar with such pedagogical technologies as mobile learning $(100 \%)$, elearning $(98 \%)$, independent learning $(90 \%)$, virtual classroom $(85 \%)$, and massive open online courses (MOOC) $(\mathbf{7 1 \%})$. The study found that teachers need to improve digital competency from technologies such as Gamification and Next Generation Digital Learning Environment (NGDLE). Based on statistical data, it was found that the need for competent specialists in vocational education in the labor market is increasing every year, while those willing to study at vocational education institutions are decreasing every year. According to the negative trends, it has been determined that vocational education institutions should improve the educational
\end{abstract}

process to increase the number of future competent specialists for the labor market.

Keywords-educational institution, professional education, pedagogical technologies, specialist.

\section{INTRODUCTION}

NFORMATION and communication technology (ICT) is becoming the leading for the international education system since they transmit information and knowledge in various areas of professional development for the vocational education system. Modern education is the main mechanism that responsible for the dissemination of knowledge and ICT. According to the rapid ICT development, all professional education staff and future professionals in vocational education must be ready to meet the new culture of teaching and learning, based on the requirements of the 21 st century on pedagogical technology [1], [2], to develop and increase the number of knowledgeable and qualified students, lead the economic development [3].

As part of the application of pedagogical technologies, educational institutions that should prepare professionals for life in the "knowledge society" should integrate pedagogical technologies in Ukrainian vocational education [4]. Together with the preparation of future professionals for the current digital era, teachers are seen as key players in the application of pedagogical technologies in their curricula, explained by the ability of educational technologies to provide dynamic and active teaching and learning environment [5], [6].

Pedagogical technologies in Ukrainian vocational education are an objective requirement for the sustainable development of the social economy [7]. Providing the process of informatization of vocational education is a key approach for Ukraine to increase the international competitiveness of vocational education in Ukraine, strengthen the connotation of 
the development of vocational education, and promote the reform of models of teaching vocational education [8]. Currently, the application of pedagogical technologies in Ukrainian vocational education faces such problems as a weak information concept of vocational education, teachers' information literacy, which has yet to be improved, imperfect information protection mechanism, and weak internal and external conditions for the application of pedagogical technologies [9].

The progressive development of pedagogical technologies in the educational process requires teachers to use learning models integrated with information and communication technologies. The use of pedagogical technologies in Ukrainian vocational education should be proportional and correspond to the needs of learning [10].

Understanding technology's importance becoming more and more significant in the workplace of modern academic staff, competing with students' knowledge and needs in the 21stcentury simply necessitates the need for pedagogical technologies finesse. But innovations can be a source of challenges for teachers and students as well.

The research aims are to establish patterns for promoting the implementation of pedagogical technologies in educational institutions for providing quality competent training of specialists in professional education.

The research tasks are:

1. To carry out an analysis of professional (vocational) education in Ukraine from 1990 to 2020.

2. To survey students and teachers about the ability of educational institutions to provide knowledge and quality competent training of specialists in Ukrainian vocational education based on the application of pedagogical technologies.

3. To propose a model of pedagogical technologies implementation in vocational education institutions.

4. To analyze the frequency of teachers' application of pedagogical technologies for the competent training of specialists in Ukrainian vocational education.

5. To conduct a comparative characterization of students' awareness of pedagogical technologies used in an educational institution and the types of pedagogical technologies used by teachers in the curriculum.

\section{LiterATURE REVIEW}

The current economy is characterized by a growing role of information and human capital in the organization of modern businesses and services. Knowledge and technology have expanded limited economic resources, offered customers radically new types of goods and services, and enabled the growth of public companies that are dynamically innovating globally [11]. Several factors are contributing to these trends. First and foremost are globalization and the digitalization of economic relationships. Digitalization allows the interconnection of knowledge, education, business, and the market to come closer, and globalization erases the boundaries of national economies [12].

The political, social, and economic changes that have recently occurred in Europe have led to some transformations and changes in the educational sphere. Since Ukrainian education is on its way to enter the European educational space, there is a need for significant changes in the whole system of professional education and its significant renewal [13]. The modern stage of world pedagogical science development is characterized by the adoption of innovation as an important factor of social reproduction, which can ensure sustainable economic development based on achieving competitiveness of the country. Therefore, the main task of public policy in Ukraine is the formation of institutional mechanisms and infrastructure of innovative ways of strategic modernization of professional education. The implementation of strategic tasks of competent training of specialists in Ukrainian vocational education requires new approaches for the transition of quantitative level indicators to qualitative ones. Of particular importance is the use of appropriate strategies for training specialists in Ukrainian vocational education in the competitive labor market, based on the principles of pedagogical technologies [14].

Rapid political, economic, and social changes in society have gained such a pace that the system of training specialists faced difficulties in meeting the requirements of the constantly changing environment. The impact of globalization processes and the rapid development of technology require an immediate response from the education system to train competitive professionals in vocational education. The traditional role of the academic educator (transmission and reproduction of instructional materials) is being changed by several new roles. The modern teacher should be able to choose and use electronic resources, pedagogical technologies for teaching students; organize cooperation and communication between participants of the educational process; develop an electronic implementation of pedagogical technologies in educational resources and educational electronic environment; be a facilitator and helper for students, understand and consider their needs and characteristics in the learning process, cognitive learning styles, new services and tools for effective cooperation.

The Future Institute in its 2020 study, identifies 10 important skills for future success: understanding meanings; social intelligence; the ability to think outside the box and rules; adaptive thinking; intercultural competence; computational thinking; media literacy; interdisciplinarity; design thinking; information management; and the ability to work remotely. At the end of 2020, the Institute of the Future added three core skills to its list: self-motivation, time management while managing your income sources, and online recruitment management [15].

According to the Organization for Economic Cooperation and Development [16] and Gbenga [17], the effectiveness of pedagogical technologies for competent training in Ukrainian vocational education forms the following advantages: they can 
be used to teach students the skills they will require in further education, throughout their lives, and for their future work; they can provide access to information and communication outside the classroom of the educational institution; the ability to use to support pedagogical development of the faculty.

Jones and Preece noted that teachers must be confident and competent in using a variety of pedagogical technology tools to provide competent training in professional education [18]. Without the competence and skill of teachers to integrate pedagogical technology that meets their needs, pedagogical technology could not be used appropriately for learning. In this regard, teachers must have some different technical and communication skills, which include the use of chat rooms, word processing skills, web page creation, and the use of different types of pedagogical technology tools [6].

The modern stage of development of human civilization makes rather high demands on their professional competence. The effectiveness of the pedagogical process in some institutions of higher education remains low because some teachers use traditional methods, not adapted to the existing conditions of the educational process. A small number of scientific and pedagogical staff have innovative pedagogical technologies that solve only a few learning objectives. However, some teachers do not have innovative technologies that comprehensively and effectively solve modern pedagogical tasks, as pointed out by many researchers [19][24].

Because of the low effectiveness of pedagogical technologies implemented by teachers, the quality of competent training of specialists in Ukrainian vocational education remains low, as evidenced by the level of final and intermediate results of some educational organizations. One of the important ways to improve the effectiveness of the pedagogical process in the education system is the integration of pedagogical technologies, the introduction of flexible integrated pedagogical technologies that can adapt to different levels of pedagogical conditions and effectively solve modern educational problems [25]-[27].

Research confirms that the implementation of pedagogical technologies and digitization in the educational sector is a rather heterogeneous process in all countries and lags behind other sectors [28]-[30]. The main goal of continuing professional education development is to benefit from providing the curriculum with digital tools, through pedagogical technologies (Köhler, Drummer, 2018). In this regard, the role of pedagogical technologies in lifelong learning has recently been affirmed in the Incheon Declaration on Education 2030 [31].

To meet the needs of today's economy and labor market, education must go beyond tradition. The new concept of Education 3.0 focuses entirely on the student, which provides a personal trajectory for each student and pays attention to the new skills and abilities acquired by students, rather than simple grades as proof that a particular subject has been learned [32]. To successfully implement Education 3.0, the use of pedagogical technologies and digital tools within the learning process becomes a necessity rather than a fad [33].

To facilitate the process of application of pedagogical technologies in Ukrainian vocational education, it is necessary to pay attention to the main works of informatization of vocational education, guarantee the implementation of software and hardware, improve the level of information of teachers, create quality information about vocational education, promote the construction of information resources, implement a balanced development of informatization, innovative models to promote informatization of vocational education.

So, the problem of implementation of pedagogical technologies of competent training in Ukrainian vocational education and research obstacles and prospects for student learning is widely reflected in scientific publications in the form of theoretical studies and practical research. However, the issues of promoting the application of pedagogical technologies in vocational education institutions remain relevant and open for further research.

\section{MethodS AND MATERIALS}

The implementation of the goal of this exploration involves the use of research methods such as:

- systematization - for developing the model of implementation of pedagogical technologies in vocational education institutions, to ensure effective training of specialists in Ukrainian vocational education;

- systematic and logical analysis, method of synthesis - for information search and setting the frequency of pedagogical technologies for the competent training of specialists in Ukrainian vocational education

- summarizing - for investigation the latest scientific publications and statistical data published by the government and reporting organizations on the state of vocational (vocational) education in Ukraine from 1990 to 2020 based on statistical information of the State Statistics Service of Ukraine;

- comparison method - to distinguishing the characteristics of students' awareness of pedagogical technologies used in the educational institution and the application of pedagogical technologies by teachers in the curriculum.

To determine teachers' and students' perceptions of the ability of educational institutions to provide knowledge and quality competent training of specialists in Ukrainian professional education through the use of pedagogical technologies a survey was conducted. An online survey was conducted from January 20 to July 30, 2021 among 5,000 students and 500 faculty from different Ukrainian educational institutions: Educational and methodological center for professional and technical education (Dnipropetrovsk region), Mariupol construction college, Lviv college of tourism, and restaurant service, State professional and technical educational institution "Chernihiv Higher Professional School", communal institution "Zaporizhzhya region institute of postgraduate 
pedagogical education" (Zaporizhzhya region), the Nadbuzsky professional agrarian lyceum, the State professional education institution "Shostka higher professional college", the Higher professional shipbuilding school in Mykolaiv, Poltava professional lyceum, and Rivne professional lyceum.

The participants answered questions about their learning experiences, motivation, expectations, and overall satisfaction with pedagogical technology. The following research questions were addressed in the online survey:

1. What are students' perceptions of pedagogical technologies to ensure effective training in Ukrainian professional education?

2. What is students' perception of the ability to assimilate information in the context of the application of pedagogical technologies to ensure effective training of specialists in Ukrainian vocational education?

3. Are there any shortcomings in the application of pedagogical technologies to provide effective training of specialists in Ukrainian vocational education?

4. Which of the pedagogical technologies do you know?

5. List the pedagogical technologies that you use in your curriculum.

6. Where do you find the main information for the professional purpose?

7. Do you constantly use pedagogical technologies for the competent training of specialists in Ukrainian vocational education?

Determining of pedagogical technologies features was conducted using descriptive statistics, the data of which were provided by a survey using MS Forms Pro.

\section{RESULTS}

According to the statistical data of the State Statistics Service of Ukraine for the period from 1990 to 2019. Figure 1 shows a downward trend in the number of institutions of vocational (vocational and technical) education; pupils, trainees in institutions of vocational (vocational and technical) education; persons admitted to study at institutions of vocational (vocational and technical) education and persons released from institutions of vocational (vocational and technical) education. This process is negative because every year there is a growing demand for competent professionals in the labor market.

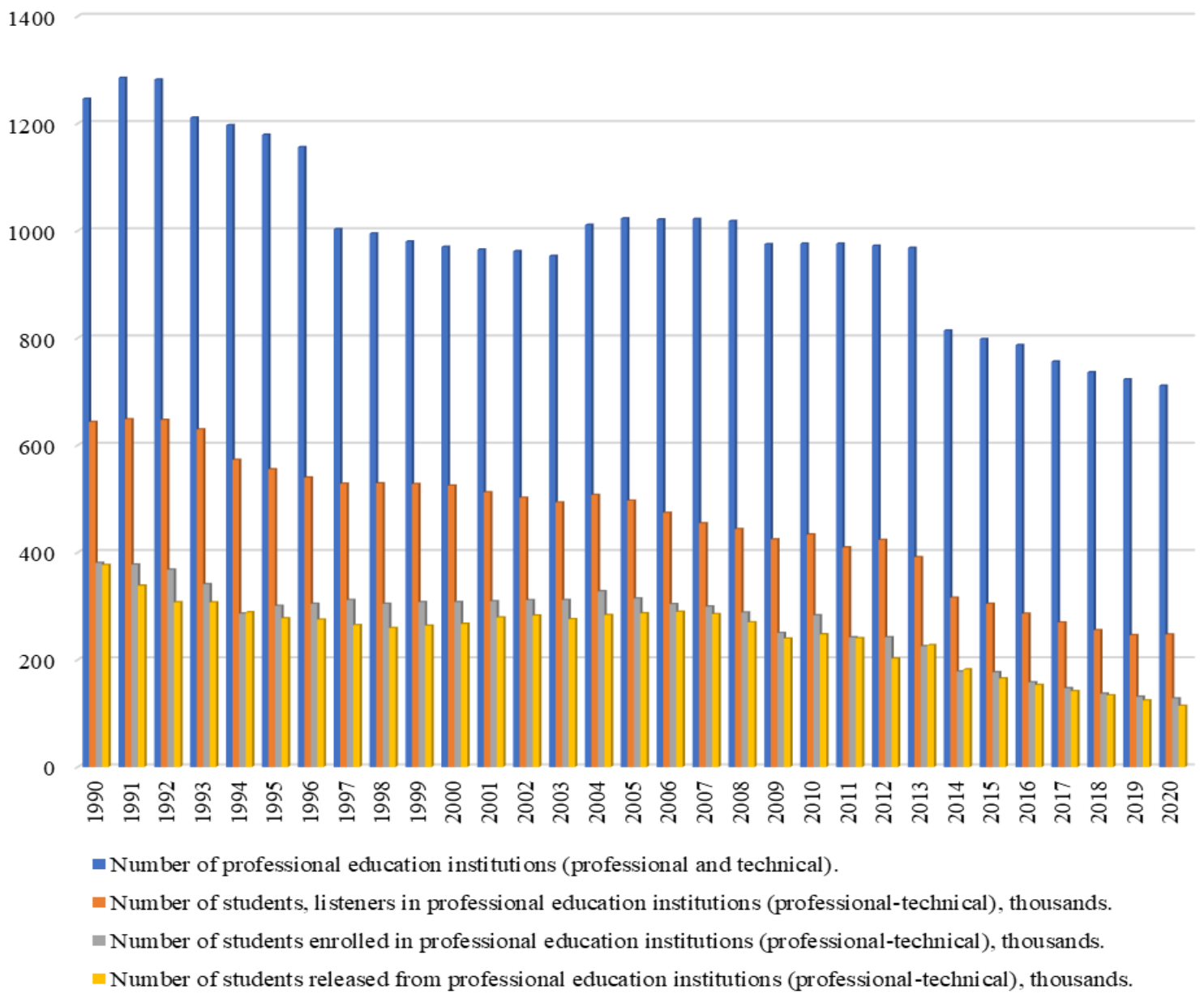

Fig. 1 The state of professional (professional-technical) education in Ukraine in 1990-2020th Source: Compiled by the authors based on official data of The State Statistics Service of Ukraine [34]. 
To evaluate the effectiveness of the use of pedagogical technologies for the competent training of teachers in Ukrainian vocational education in 2021. Students of the Educational and methodological center for professional and technical education in Dnipropetrovsk region, Mariupol construction college, Lviv college of tourism and restaurant service, State professional and technical educational institution "Chernihiv Higher Professional School", The communal institution "Zaporizhzhya region institute of postgraduate pedagogical education" of Zaporizhzhya region administration, the Nadbuzsky professional agrarian lyceum, the State professional education institution "Shostka higher

Rivne professional lyceum

Poltava professional lyceum

Higher professional shipbuilding school in Mykolaiv

State professi onal education institution "Shostka higher professional college"

Nadbuzsky professional agrarian lyceum

Communal institution "Zaporizhzhya region institute of postgraduate pedagogical education" of Zaporizhzhya region administration

State professional and technical educational institution "Chernihiv higher professional college"

Lviv college of tourism and hotel and restaurant service

Mariupol construction college

Educational and methodological center for professional and technical education in Dnipropetrovsk region

professional college", the Higher professional shipbuilding school in Mykolaiv, Poltava professional lyceum, and Rivne professional lyceum. Most of the respondents (89.7\%) indicated that educational technology has a positive impact on ensuring the competent training of teachers in the Ukrainian vocational education $(89.7 \%)$, a smaller number $(7,5 \%)$ were not convinced about the quality of the competent training of teachers in Ukrainian professional education by modern pedagogical technologies, and the students stated, that modern pedagogical technologies of competent training of teachers in Ukrainian professional education have some shortcomings $(2.8 \%)$ (see Fig. 2.).

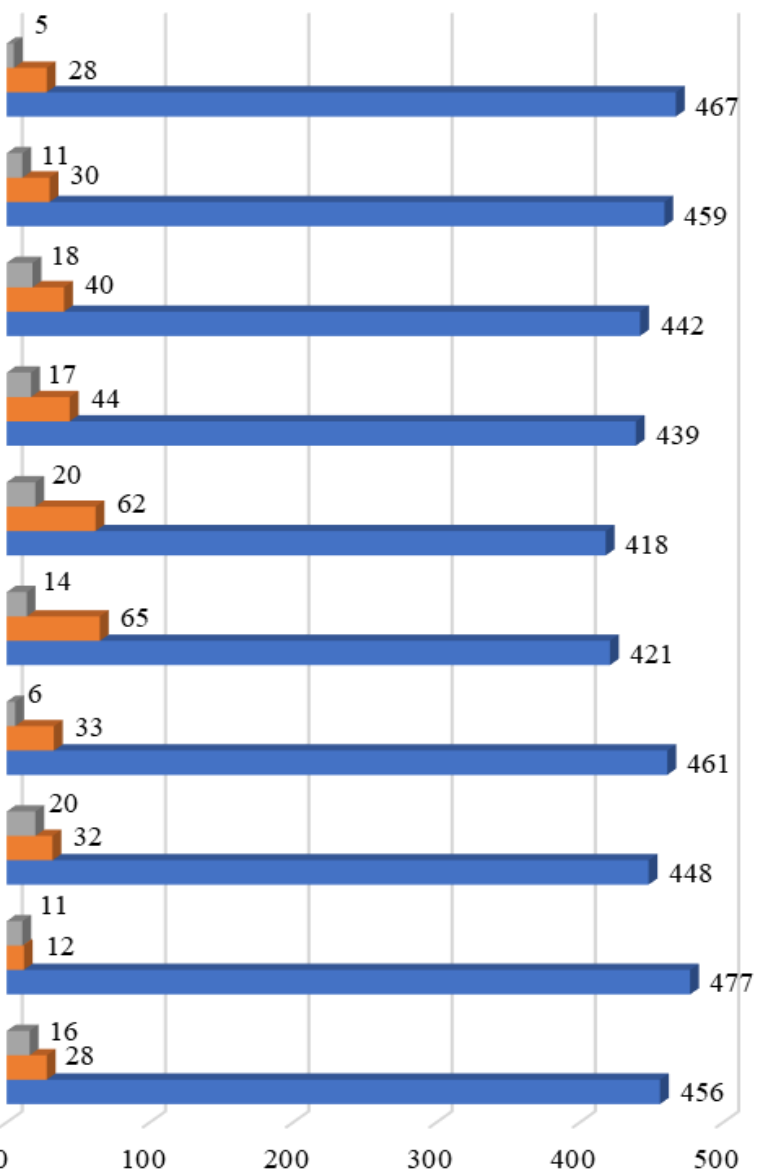

$\square$ the modern pedagogical technologies for competent teachers training in Ukrainian professional education hav some shortcomings

Eare not convinced of the quality of competent teachers training in Ukrainian professional education with modern pedagogical technologies

- pedagogical technologies positively influence on providing competent teachers training in Ukrainian professional education

Fig. 2 Analysis of pedagogical technologies trends for competent training of teachers in Ukrainian professional education in 2021

Source: Compiled by the authors.

To the question: "Which of the pedagogical technologies listed below are familiar to you?" respondents noted that they are the most familiar with: Mobile learning (100\%), e-learning (98\%), self-study (90\%), virtual classroom (85\%), and Massive Open Online Courses (MOOCs) (71\%), and least familiar with LCMS (learning content management system) (1\%), Course Management System (CMS) (2\%), Next Generation Digital Learning Environment (NGDLE) (4\%), Personnel Integrated Education System (PIES) (4\%) (see Fig. $3)$. 


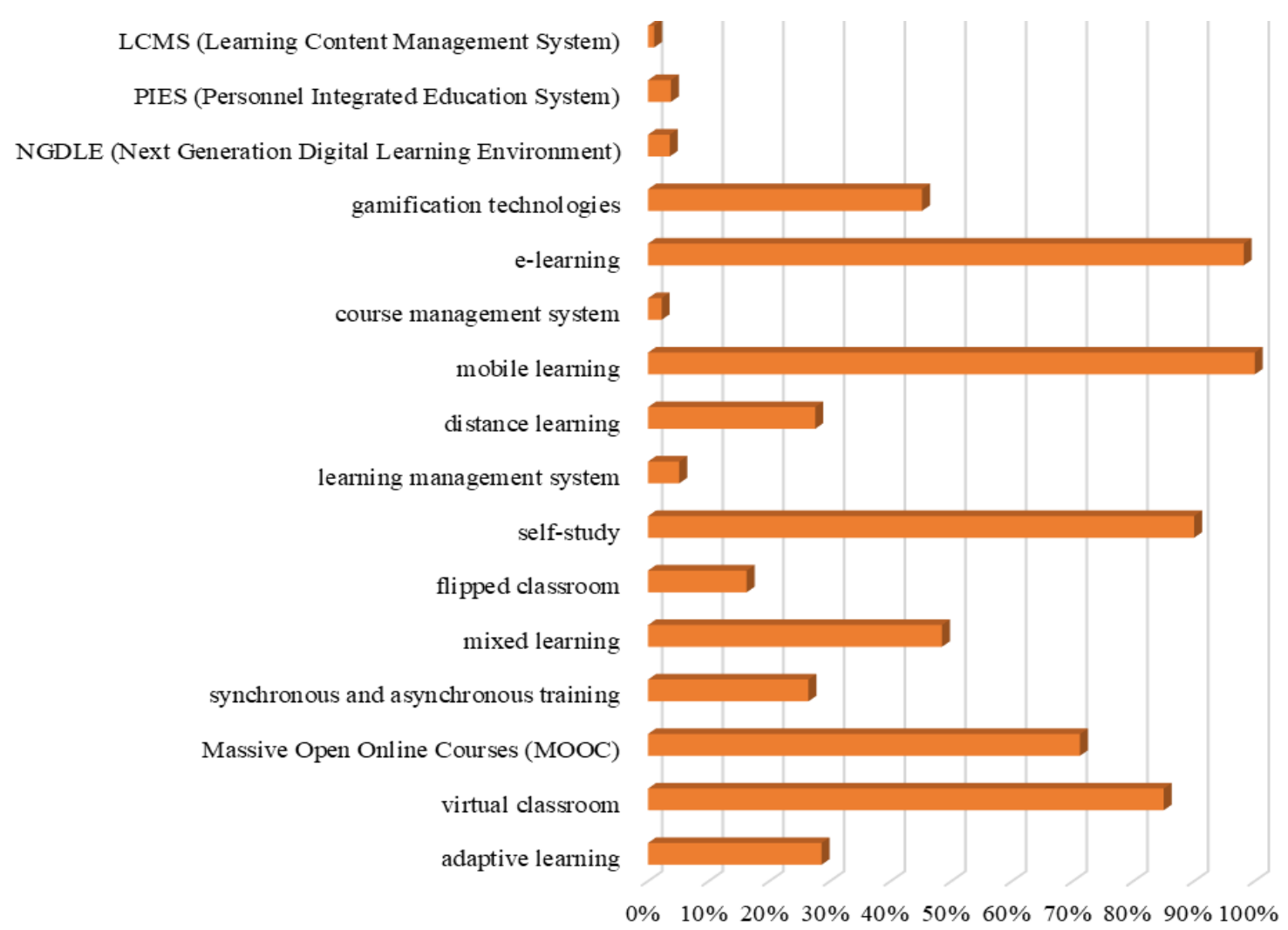

Fig. 3 Which of the pedagogical technologies listed below are familiar to you?

Source: Compiled by the authors.

Thus, we can say that students are aware of modern digital technologies. To the question "List the pedagogical technologies you use in the educational program?" respondents noted that the following pedagogical technologies are used the most: E-learning (100\%), mobile learning (99\%), self-study $(95 \%)$, blended learning $(93 \%)$, and learning content management system (LCMS) (91\%), and the least used are technologies of gamification $(27 \%)$ and Next Generation Digital Learning Environment (NGDLE) (29\%). Therefore, digital technologies are generally known to teachers, but not all of them are used in their professional activities (see Fig. 4).

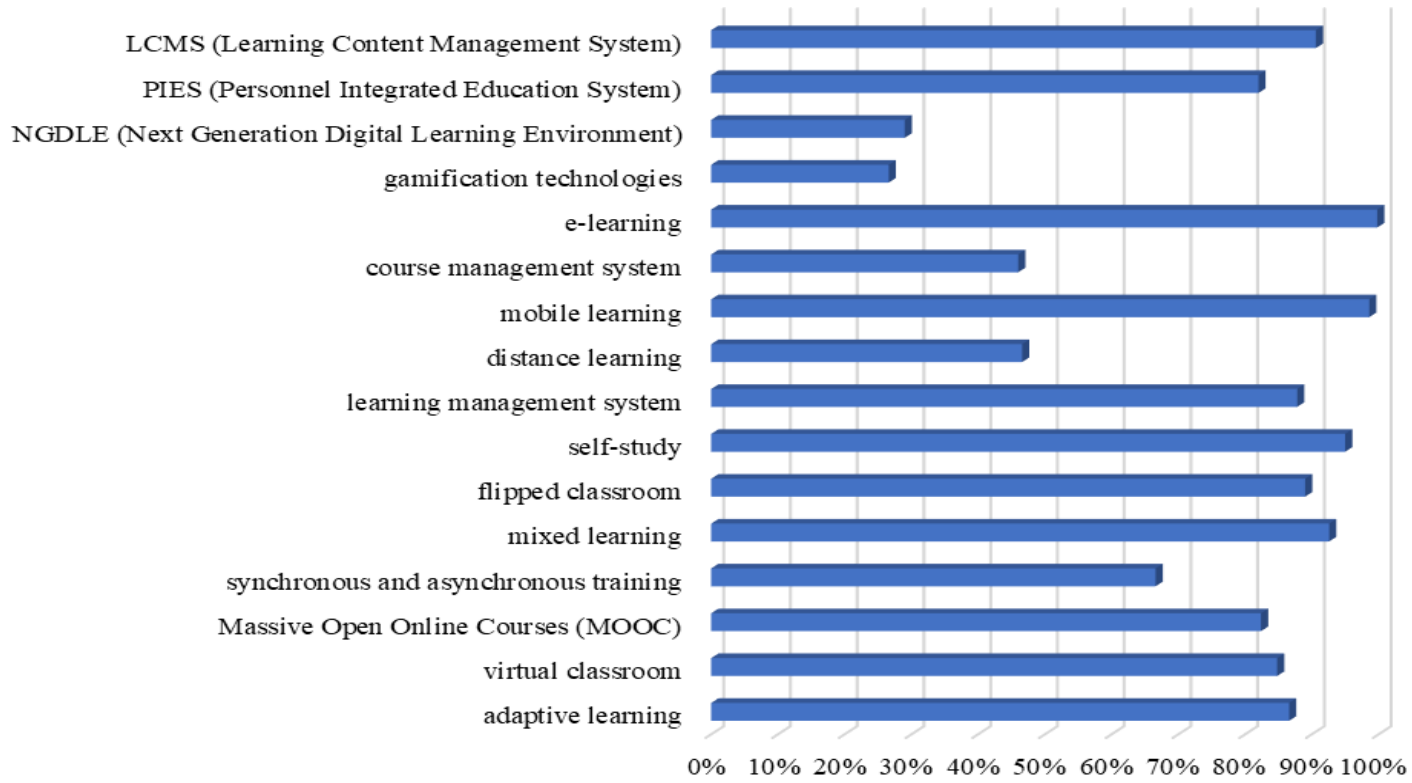

Fig. 4 Which pedagogical technologies you use in your teaching program? List it.

Source: Compiled by the authors. 
To the question "Do you constantly use pedagogical technologies for competent training of teachers in Ukrainian professional education?" (see Fig. 5a) respondents said "yes"

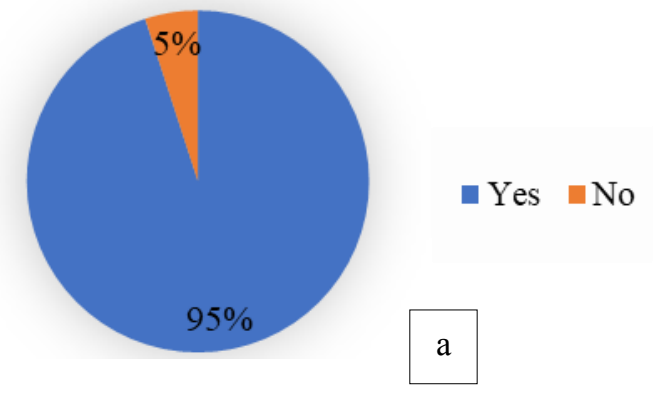

(95\%), and 5\% said "no". To the question "Where do you find the main professional information?" (see Fig. 5b) respondents used Internet resources (88\%), and textbooks $(12 \%)$.

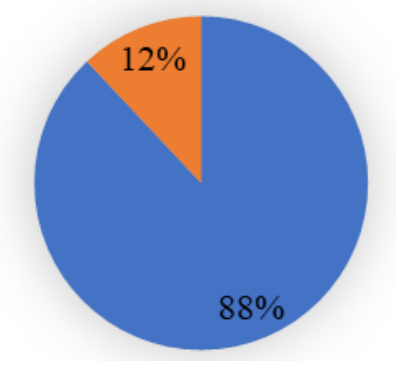

nard-copy manuals

$\mathrm{b}$

Fig. 5 Respondents' answers about pedagogical technologies and professional information Source: Compiled by the authors.

The theoretical and predictive model of implementation of pedagogical technologies in vocational education institutions (see Fig. 6) is based on general scientific methodology, taking into account external and internal factors that affect the ability of educational institutions to provide knowledge and competent training of teachers in Ukrainian vocational education based on pedagogical technologies.

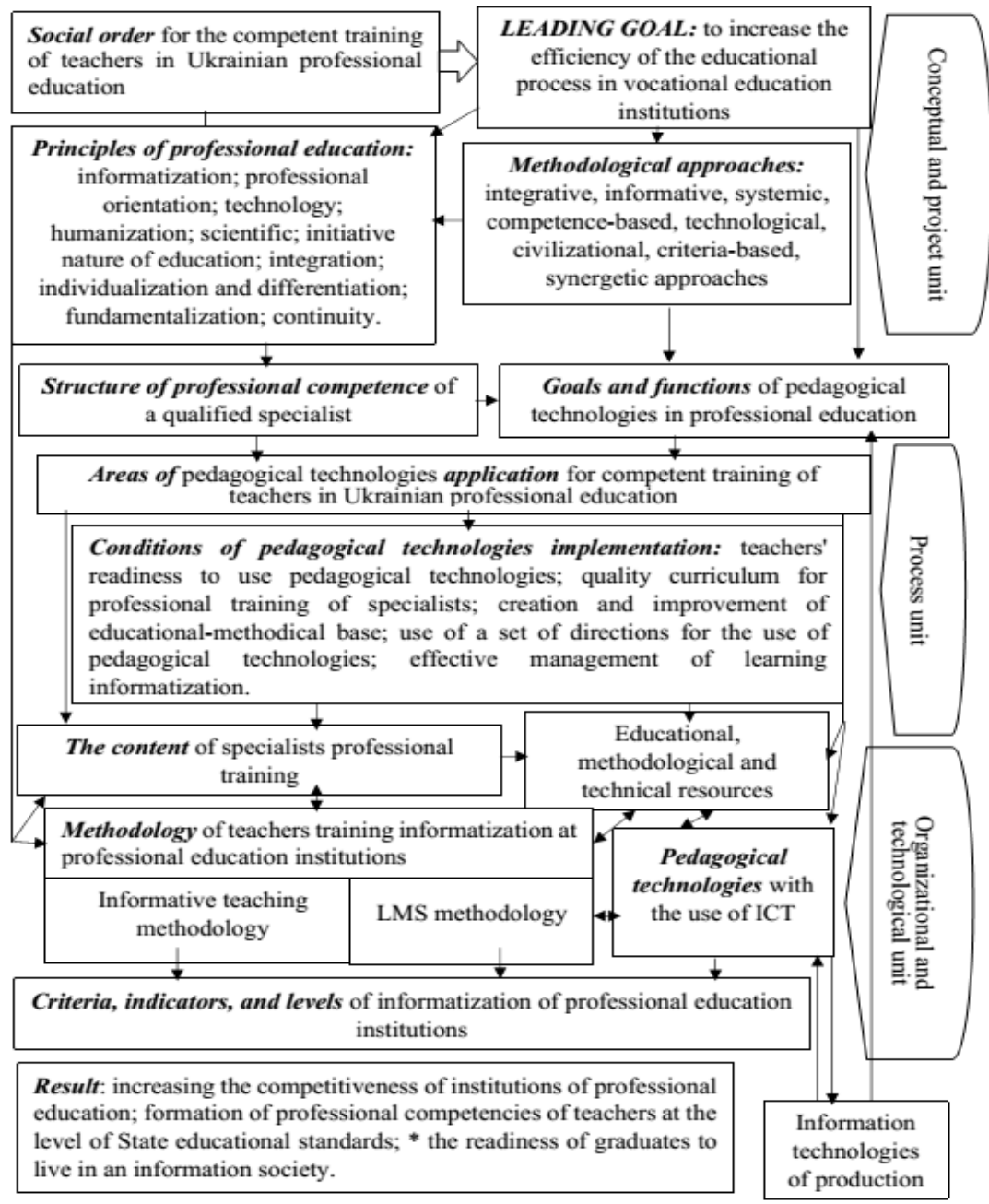

Fig. 6 Model of pedagogical technologies implementation in the professional education institutions Source: Compiled by the authors based on [35].

This model asecurates interconnected conceptual and design, process, and organizational-technological blocks that 
coordinate all elements of pedagogical technologies of the educational process of vocational education institutions. The conceptual and design block represents the initial methodological and psychological and pedagogical positions of the pedagogical technologies' implementation process. The process block defines the specific characteristics of educational institutions' activities due to the conditions of pedagogical technologies application. The third block of the model demonstrates the material, technical, and educationalmethodological base of pedagogical technologies of vocational education institutions.

\section{DISCUSSION}

The results of the study of pedagogical technologies for the competent training of specialists in Ukrainian vocational education have led to the following conclusions.

The planning and implementation of pedagogical technologies and information resources that would provide targeted and competent training of specialists in Ukrainian professional education are in high demand. Eslami and Ahmadi (2019), noted that educational institutions are increasingly required to use the potential of pedagogical technologies to provide quality knowledge and skills of students.

The findings indicate that despite significant advances in this area and the development of the problem in general [19][24], the possibilities of optimizing the training of qualified specialists through the use of pedagogical technologies have not been studied enough, no comprehensive analysis and classification of relevant educational software and other electronic learning tools have been conducted, there are no clear methods for assessing the quality of information resources and technologies used in Ukrainian vocational education.

The problem of using pedagogical technologies to ensure effective training of specialists in vocational education is widely spread among scientific works of modern scientists [36]-[37]. The current state of information provision of vocational education does not fully meet the expectations of users of educational services, so it requires a scientific reorientation of educational goals and pedagogical technologies [35].

The development of vocational education is directly related to changes in the worldview and mindset of teachers and students, who are the main participants in the educational process. Teachers must provide a learning process in which each student needs to have a strong motivation for their chosen specialty, as well as a strong motivation to succeed in life or the need to achieve success [38]. Competent training of specialists in Ukrainian professional education is to create certain socio-pedagogical conditions based on the application of pedagogical technologies in the educational institution to influence the activation of the potential of future professionals, to develop professional motivation and motivation to succeed in the process to ensure the quality of professional training
[27]. In an environment constantly changing, teachers must develop and implement new educational programs that take into account the latest scientific advances, systematically selfimprovement, constantly update knowledge, update methods, organizational forms, and means of work to prepare students for the vital challenges in future professional activities [39].

The implementation of the proposed model contributes to the process of optimization and structuring of information learning, by selecting appropriate pedagogical technologies, developing methodological support for the educational process, and coordinating the efforts of teachers [35]. The management of the educational process in a globalized and digitalized educational environment presents its efficiency and effectiveness through indicators that are not directly related to learning activities, such as the availability of plans, procedures, number and qualifications of the staff, the ratio of students to staff or different results on employment rates, their salary levels, etc. [40].

So, teachers and students will face new problems, because the potential of pedagogical technologies for the competent training of specialists in the educational information technology space is high enough, but not enough realized, indepth research, which will lead to increased attention to improving the training of specialists in professional education.

\section{CONCLUSION}

The results of the study of pedagogical technologies for competent training of specialists in Ukrainian vocational education have led to the following conclusions. The use of pedagogical technologies in managing the educational process undoubtedly requires the development of technological infrastructure of professional educational environment: the introduction of computer equipment, network support, information terminals, educational and methodological techniques, and technical support of information technologies, as well as developing a strategy to equip educational institutions with the necessary educational software.

Pedagogical technologies should be used in all cycles of vocational training. The administration of educational institutions should develop a long-term program for the implementation of pedagogical technologies aimed at the introduction of automation of the management of the educational process. This makes it possible to increase management efficiency, students' learning productivity, competence training of future specialists, due to providing powerful feedback in the educational system.

The results obtained in the course of the study allow us to identify directions for further exploration of scientific and methodological foundations for the development of teachers' digital competence to ensure the professional training of competent specialists. Continuous improvement in the level of digital competence, allows the teacher to use pedagogical technologies for search, logical selection, systematization, use of educational material, and organization of the successful educational process. 
The practical significance of the conducted research lies in the fact that the conclusions and recommendations developed by the author and offered in the article can be used for avoiding interference in the implementation of pedagogical technologies for the competent training of specialists in vocational education.

Further research can be aimed at improving the curriculum using pedagogical technologies in vocational education institutions to train students, which will stimulate the educational sphere and improve teaching activities in the educational information and technological space, which will ensure quality vocational education. Expanding the opportunities and wide application of innovative, researchbased approaches to ensure competent training of specialists in professional education, which can become the basis for the improvement of educational programs.

\section{References}

[1] C. S. Chai, L. Tan, F. Deng, J. H. L. Koh, "Examining pre-service teachers' design capacities for a web-based 21 st-century new culture of learning," Australasian Journal of Educational Technology, 33(1), 2017, pp. 120.

[2] D. O. Göksün, A. A. Kurt, "The relationship between preservice teachers' use of 21 st Century learner skills and 21st Century teacher skills," Egitim ve Bilim, 42(190), 2017, pp. 107-130. DOI: 10.15390/EB.2017.7089.

[3] R. Abdelmoiz, C. Xiaohui, L. Hudson “Teachers' Skills and ICT Integration in Technical and Vocational Education and Training TVET: A Case of Khartoum State-Sudan," World Journal of Education, 8, 31, 2018. DOI: $10.5430 /$ wje.v8n3p31.

[4] S. Ghavifekr, M. Afshari, Salleh Amla, "Management strategies for E-Learning system as the core component of systemic change: A qualitative analysis," Life Science Journal, 9(3), 2012, pp. 2190-2196.

[5] H. C. Arnseth, O. E. Hatlevik, "Challenges in aligning pedagogical practices and pupils' competencies with the Information Society's demands: The case of Norway", In S. Mukerji \& P. Triphati (Eds.), Cases on technological adaptability and transnational learning: Issues and challenges. Hershey: IGI global. 2010.

[6] S. Ghavifekr, A.Z.A.Razak, M.F.A. Ghani, N.Y. Ran, Y. Meixi, Z. Tengyue, "ICT Integration In Education: Incorporation For Teaching \& Learning Improvement," Malaysian Online Journal of Educational Technology, 2(2), 2014, pp. 24-45.

[7] A. Adıgüzel, İ. Yüksel, “Öğretmenlerin öğretim teknolojileri entegrasyon becerilerinin değerlendirilmesi: Yenipedagojik yaklaşımlar için nitel bir gereksinim analizi." Necatibey Eğitim Fakültesi Elektronik Fen ve Matematik Eğitimi Dergisi, 6(1), 2012, pp. 265-286.

[8] J. Ainley, M. Luntley "Towards an articulation of expert classroom practice," Teaching and Teacher Education, 23(7), 2007, pp. 1127-1138.

[9] D. Orhan-Goksun, A. Askım-Kurt, "The relationship between pre-service teachers' use of 21 st-century learner skills and use of 21st-century teacher skills," Education and Science, 42(190), 2017, pp. 107-130. DOI:10.15390/EB.2017.7089.

[10] A. Aprinaldi, I. Widiaty, A. Gafar Abdullah, "Integrating SAMR learning model in vocational education," IOP Conference Series: Materials Science and Engineering, 434, 012309, 2018, DOI: 10.1088/1757899X/434/1/012309.

[11]R. R. R. Singareddy, P. Ranjan, A.Balamurugan, C. Shabana, "Financial inclusion remodeling: Including the excluded masses," Space and Culture, India, 6(5), 2019, pp. 178-188. DOI: 10.20896/SACI.V6I5.375.

[12] V.L. Vasilev, A.R. Gapsalamov, E. Akhmetshin, T. Bochkareva, A. Yumashev, T. Anisimova, "Digitalization peculiarities of organizations: a case study," Entrepreneurship and Sustainability, 7, 2020, pp. 31733190.

[13]I. Sheludko, "Achievements in the training of future technology teachers: the European experience," Comparative Professional Pedagogy, 5 (2), 2015. pp. 9296

[14]I. Sheludko, "The Training of Qualified Specialists in the Countries of the Black Sea Region in the Context of Globalization Education Processes." Comparative Professional Pedagogy, 7(2), 2017, pp. 76-80.

[15] Council Recommendation of 22 May 2018 on key competences for lifelong learning (Text with EEA relevance) (2018/C 189/01). (2018). Available: https://eur-lex.europa.eu/legalcontent/EN/TXT/PDF/?uri=CELEX:32018H0604(01)\&ri $\mathrm{d}=7$.

[16] Organization for Economic Co-Operation and Development (OECD). Annual Report Prepared by the Public Affairs Division, Public Affairs, and Communications Directorate. Published under the responsibility of the Secretary-General of the OECD. 2005.

[17] A. Gbenga, "Information and communication technology and web mining techniques," Paper presented at Education Trust Fund Capacity Building Workshop for Knowledge-driven Growth for Nigerian Universities North-central zone held at the University of Ilorin, 2006.

[18] A. Jones, J. Preece, "Online communities for teachers and lifelong learners: A framework for comparing similarities and identifying differences in communities of practice and communities of interest," International Journal of Learning Technology, 2(2), 2006, pp. 112-137.

[19]S. Kashisaz, E. Mobaraki, "The Effects of Private Education Institutes in Providing Modern Financial Knowledge in Developing Countries," Journal of Humanities Insights, 02(04), 2018, pp. 172-178. DOI: $0.22034 /$ jhi.2018.80887.

[20]M. A. Kheirabadi, Z. Mirzaei, "Descriptive valuation pattern in education and training system: a mixed study," Journal of Humanities Insights, 3(01), 2019, pp. 7-12. DOI: $10.22034 /$ jhi.2019.80889.

[21]E. K. Kuzmina, G. I. Nazarova, L. R. Nizamieva, C. Leblanc, "Innovative Technologies of Teaching Business 
French," International Journal of Engineering \& Technology, 7 (4.7), 2018, pp. 85-87. Available: https://www.

sciencepubco.com/index.php/ijet/article/view/20390/9555

[22] E. K. Kuzmina, V. N. Vassilieva, A. F. Valeeva, E. R. Porshneva, "Techno-R" Technology in Teaching the Students of Linguistic Direction the Latin Language, HELIX, 8(1), 2018, pp. 2178-2181. Available: http://helix.dnares.in/wp-content/uploads/2018/02/21782181.852.pdf.

[23] Nakhaee, M. A.Nasrabadi, "Strategies for ResearchCentered Education of Architectural Designing by Examining the Research-Centered Activities of the Top Universities," Journal of Humanities Insights, 3(02), 2019,pp. 50-56. DOI: 10.22034/jhi.2019.80898.

[24]I. Jasur, A. Nilufar, "Personal names spell-checking - a study related to Uzbek," UCT Journal of Social Sciences and Humanities Research, 6(1), 2018, pp. 1-6.

[25] L. Y. Grudtsina, A. V.Filippova, E. V. Makarova, D.L. Kondratyuk, V. E. Usanov, S. V. Molchanov, "Preventive Pedagogy: Methods of Research University Students' Readiness Formation for a Healthy Lifestyle," International Electronic Journal of Mathematics Education, 12(1), 2017,pp. 51-58. Available: https:/www.iejme.com/article/preventive-pedagogymethods-ofresearch-university-students-readinessformation-for-a-healthy.

[26]R. Eslami, S. Ahmadi, "Investigating the Role of Educational Media on Secondary School Students' Learning Process Improvement in Jahrom City," Journal of Humanities Insights, 3(01), 2019, pp. 13-6. DOI: 10.22034/ jhi.2019.80890.

[27] E. Jabbari, Z. Charbaghi, A. Dana, "Investigating the Effects of Educational and Motivational Education at Different Levels on the Performance and Application of dart throwing," Journal of Humanities Insights, 3(02), 2019, pp. 37-44. DOI: 10.22034/jhi.2019.80896.

[28]G. Erber, T. Köhler, C. Lattemann, B. Preissl, J. Rentmeister, "Rahmenbedingungen für eine Breitbandoffensive in Deutschland," Berlin: Deutsches Institut für Wirtschaft. 2004.

[29]T. Köhler, J. Drummer, "Recent Technological Challenges in (Vocational) Educatio," Vocational Teacher Education in Central Asia. Developing Skills and Facilitating Success. Technical and Vocational Education and Training: Issues, Concerns, and Prospects 28. 2018, pp. 3-14.

[30]D. Pscheida, C. Minet, S. Herbst, S. Albrecht, T. Köhler, "Use of social media and online-based tools in academia," Results of the science 2.0-survey 2014. Dresden: TUD Press. Available: http://nbnresolving.de/urn:nbn:de:bsz:14-qucosa-191110.

[31] UNESCO. "Education 2030 - Incheon declaration," Paris: UNESCO. 2016.

[32] M. K. Govindasamy, N. M. Kwe, "Scaffolding problemsolving in teaching and learning the DPACE Model-A design thinking approach," Research in Social Sciences \& Technology, 5(2), 2020, pp. 93-112.
[33] V. P. Kupriyanovskij, S. A. Sinyagov, D. E. Namiot, A. P. Dobrynin, C. Hernyh, K. Yu, "Information technologies in the system of universities, science, and innovations in the digital economy on the example of Great Britain," International Journal of Open Information Technologies, 4(4), 2016.

[34] The State Statistics Service of Ukraine. Institutions of professional (vocational) education. Available: http://www.ukrstat.gov.ua/operativ/operativ2005/osv_rik/ osv_u/ptu_u.html.

[35] A. Lytvyn, V. Lytvyn, L. Rudenko, et al., "Informatization of technical vocational schools: Theoretical foundations and practical approaches," Education and Information Technologies, 25, 2020, pp. 583-609. DOI: 10.1007/s10639-019-09966-4.

[36] P. P. Khoroshikh, A. A. Sergievich, R. I. Platonova, 'Development of students' critical thinking by active and interactive training methods," TEM Journal, 7(4), 2018, pp. 787-790. DOI:10.18421/TEM74-14.

[37] C. Morosan, M. Dawson, E. A. Whalen, "Using active learning activities to increase student outcomes in an information technology course," Journal of Hospitality and Tourism Education, 29(4), 2017, pp.147-157. DOI:10.1080/10963758.2017.1382369.

[38] G. Charness, D. Grieco, "Creativity and Incentives," Journal of the European Economic Association, Volume 17, Issue 2, 2019, pp. 454-496. DOI: $10.1093 /$ jeea/jvx055.

[39] W. Martin, A. Gersick, H. Nudell, K. M. Culp, "An evaluation of Intel teach to the future. Year Two Final Report. September 2002," Center for Children and Technology, New York. 2002, Available: https://www.academia.edu/27425031/.

[40]B. Stensaker, "Quality assurance and the battle for legitimacy - discourses, disputes and dependencies," Higher Education Evaluation and Development, 12(3/2), 2018, pp. 54-62. DOI: 10.1108/HEED-10-2018-0024.G. O. Young, "Synthetic structure of industrial plastics (Book style with paper title and editor)," in Plastics, 2nd ed. vol. 3, J. Peters, Ed. New York: McGraw-Hill, 1964, pp. 15-64.

Creative Commons Attribution License 4.0 (Attribution 4.0 International, CC BY 4.0)

This article is published under the terms of the Creative Commons Attribution License 4.0

https://creativecommons.org/licenses/by/4.0/deed.en_US 